\title{
The ecclesiological significance of the 'African kraal' metaphor in a context of urban poverty in Zimbabwe
}

\author{
Banda, Collium \\ North-West University \\ collium@gmail.com \\ Van der Merwe, IJ \\ Stellenbosch University \\ johan@concilioconsult.co.za
}

\begin{abstract}
The essay considers how the communal and empowering nature of the African kraal can be a metaphor of a liberating and empowering church in a context of urban poverty in Zimbabwe. Africans generally experience urban centres as foreign and hostile places where they ideally only live temporarily during seasons of urban employment. In Zimbabwe, poverty alleviation strategies that pay attention to the unique context of urban centres are few. This heightens the African experience of urban centres as foreign places. Urban churches often struggle to respond to urban poverty meaningfully. The African kraal, although a rural oriented metaphor, can direct the church in the city to meaningfully respond to urban poverty.
\end{abstract}

Key words

Urban poverty; urban ecclesiology; African kraal; Zimbabwe; church communality

\section{Introduction}

Although urban poverty is a growing problem in Zimbabwe, poverty alleviation programmes empowering the urban poor remain are wanting (Dhemba 1999:10). Where poverty alleviation strategies do exist in urban centres, they are usually not sufficiently informed with the dynamics of urban realities. This essay is inspired by the liberating and empowering nature of the African cattle kraal. Having in mind a Zimbabwean urban context ravaged by poverty, this essay wrestles with how an ecclesiological 
reflection on the African traditional religious values in the African kraal can assist in formulating an empowering and liberating urban ecclesiology that responds to poverty meaningfully. The essay is concerned with poverty as experienced by black African indigenous people. The essay begins by examining some core socioeconomic and political dynamics of African ${ }^{1}$ urban poverty in Zimbabwe. The essay proceeds to critically consider how the African kraal can be a positive metaphor of a liberating and empowering church in an urban context of poverty. The essay closes by examining, in the light of the African kraal metaphor, what the urban church should be and do to meaningfully respond to the context of urban poverty.

\section{Dynamics in African urban poverty in Zimbabwe}

African urban poverty in Zimbabwe has its own dynamics that need to be sufficiently appreciated by urban churches if effective strategies of poverty alleviation are to be undertaken. This section critically explores these dynamics.

\subsection{The problem of regarding Africans as foreigners in urban centres}

A significant factor in African urban poverty in Zimbabwe lies in the entrenched and prevalent belief that black people are foreigners in urban centres where they should only temporarily dwell during their brief duration of active employment. Dhemba (1999:8) points out that oppressive and segregating colonial laws including Pass Laws (1902, the Urban Registration and Accommodation Act (1934), the Vagrancy Act (1960), and the controlled lodger system, legislated Africans as temporary residents in urban areas and granted permanent urban settlement to white settlers only. African urban life was marked by socioeconomic 'deprivation and exclusion' (Hove, et. al. 2013:5) since the segregated socioeconomic life favoured white settlers. Meanwhile, colonial authorities placed African permanent settlement in rural areas where it was 'conveniently believed that they had a piece of land and relatives who could meet their social security needs' (Dhemba 1999:8). However, most rural areas were unproductive semi-arid lands and were underdeveloped; therefore, Africans remained an impoverished lot in both rural and urban centres. In post-independence

1 'African' is used in this essay to refer to the black indigenous people. 
Zimbabwe, the deportation to the rural areas of many poor black urbanites in the government's Operation Murambatsvina (Operation 'drive-outtrash') of 2005, strengthened the belief that for black people, urban centres are foreign lands to be occupied for employment purposes only.

Furthermore, the initial design of urban centres and the nature of urban life did not accept black Africans as permanent citizens. Various Zimbabwean scholars show that racially-driven colonial urban policy invested meagre resources in African urban housing causing overcrowding and withheld from them rights to own urban housing and security of tenure, all which accentuated the view of urban centres as foreign lands to Africans (Mpofu 2010:6; Chavunduka 1975:69; Mazingi \& Kamidza 2011:323). These negative factors motivated most Africans in colonial Zimbabwe to not consider urban centres as their permanent home.

Moreover, labour conditions segregated Africans; ${ }^{2}$ the wages were pitiful and African informal trading was severely restricted, which grossly hindered African efforts to augment their poor income and improve their squalid urban living conditions. ${ }^{3}$ This deep level of poverty made urban centres foreign and hostile lands to Africans who subsequently considered it extreme foolishness to invest in permanent urban interests. Colonial urban life denied Africans the power to meaningfully participate in the urban economy.

That post-independence urban life in Zimbabwe continues to be inhospitable and hostile to many black Africans is affirmed in the common Ndebele sayings such as 'Impilo yedolobheni iyaphela', (literally, urban life ends). This shows that Africans continue to approach urban life as a temporary life that comes to an end when they would have to return to their

2 For example, Mpofu highlights, 'In the 1930s, white poverty in Southern Rhodesia was attributed to unemployment and the Commissioner of Labour blamed the causes of white unemployment on the increasing capacity of Africans to compete with the whites making the unskilled and semi-skilled whites find it increasingly difficult to obtain work' (2010:9).

3 Furthermore, African life seems to have fallen victim to what Dhemba calls the convenient belief throughout the colonial era 'that poverty had not reached unacceptable levels, for information about its extent was deliberately not documented' (1999:9). This view can be supported by the fact that Rhodesia only had four poverty datum line studies, the first one was conducted in 1944, then in 1958, 1974 (Cubitt \& Riddell, 1974) and 1979 (Cubitt, 1979). 
permanent rural life. It remains common in independent Zimbabwe to find many urban home owners, even those with title deeds in posh suburbs who invest in rural homes as their final places of retirement. This indicates that many Africans conduct their economic activity under the belief that urban centres are temporary spaces and rural areas are their permanent space.

\subsection{The fall of the formal economy and the emergence of cronyism}

The recent unprecedented severe decline of the formal economy in postindependence Zimbabwe, and in some cases its complete disappearance, further intensifies the African experience of urban areas as harsh foreign lands. Mpofu highlights that from the year 2000 the formal economy severely declined to the extent that the 'middle class professionals like teachers and nurses were pauperised' (2011b:14). Recent private statistics estimate unemployment to be over 90\% (Southern Eye 2015; Mutasa 2015). However, government estimate is $11.4 \%$ (ZimStat 2014; The Herald 2015). The informal sector is volatile and often suffers from political interference and harsh state laws, making it a terrain where only the fittest and politically connected survive.

This severe decline of the formal economy, creating high levels of formal unemployment, means that many professionalised and educated Zimbabweans now roam the streets unemployed. This has severely diminished the value of the Zimbabwe's acclaimed formal educational and professional training system. Moreover, professional and educated people have abandoned formal jobs to compete with non-professionally trained people in menial informal activities such as vending and hawking (Mpofu 2011b:14). Yet, Zimbabwe churns out thousands of high school, college, university and professionalised graduates every year. Some media houses recently mocked university graduation ceremonies with such news headlines as 'Graduating to Become a Vendor, Taxi Pirate' (NewsDay Zimbabwe 2015) and 'Celebrating Sending Graduates to Streets' (DailyNews Live 2015). These seemingly mocking titles lament the diminished value of the formal economy. The few lucky graduates who manage to find employment still have to contend with poor salaries, often paid late or not paid at all. Ultimately, the value of attaining higher and professional education has severely diminished. Ironically, in colonial times education and employment featured prominently as key strategies of escaping urban poverty. 
Professional urbanites have adopted ukukiyakiya ${ }^{4}$ (exploiting whatever opportunity falls in one's way for survival's sake) or ukutshaya amadili ${ }^{5}$ (doing informal deals), dodgy informal activities which were once frowned upon and associated with lazy people looking for a quick way to make money or as tsotsis (criminals) (Mpofu 2011b:14). Furthermore, corruption, cronyism, patronage, nepotism, tribalism and profiteering (Chung 2006:269-273), have diminished the value of merit and competence by placing a high premium on political connections and not on the ability to deliver. This means that the poor who have no political connections remain excluded and have limited chances of overcoming their poverty. It is becoming increasingly entrenched in Zimbabwe that the escape from poverty now requires more than being skilled, knowledgeable and capable. When able-bodied highly educated, highly professionalised and highly skilled people have to resort to dodgy activities the first thing to lose its value is the professionalised career. This means that many urban poor people are excluded from the economic cycle, for they have no access to participate in the economy unless they are willing to pay the premium of patronage.

\subsection{The problem of unjust and unimaginative urban governance}

Urban poverty in Zimbabwe is rooted in economic injustice and corrupt unimaginative urban governance. Geneviève James observes that in her South African context resources in cities are so poorly and unjustly distributed that the poor and powerless people experience 'a major deficit of joy' (2015:58). This observation is also true in urban Zimbabwe where the poor often face the scourge of preventable diseases like cholera and dysentery due to poor sanitation and poor water supply, poorly built housing and have even fallen victim to housing scams from the ruling elite. The urban poor have also suffered as political pawns in the battle to control the urban cities by the country's major political parties, the government and the opposition parties. On several instances President

4 Ukukiyakiya, probably derived from key, carries the idea of trying many different keys to open the door because one does not know the right key that will unlock the door. The phrase captures the 'desperate exploitation of whatever resources at hand just to survive’ (Jones, in Mpofu 2011:14).

5 Ukutshaya amadili, literally meaning doing deals, refers to embarking in illegal trading or informal trading. 
Mugabe's government has implemented destructive operations like the May 2005 urban clean-up operation to destroy 'illegal' urban structures, although it seemed targeted at the urban centres administered by Morgan Tsvangirai's opposition party (Mpofu 2011a:179,181). The inhumaneness of the destructive operation seemed to affirm that the life of the poor is protected by the ruling elites only on the bases of political party allegiance and not citizenship to the country.

Zimbabwean urban centres have become places of mourning, unloved life and unprotected life where the poor are marginalised and exploited by the oppressive ruling elites (Magure 2012:68). Poor post-independent economic policies and corrupt governance that have resulted in massive de-industrialisation instead of promoting massive industrialisation have given urban poverty momentum in Zimbabwe. Furthermore, as Dhemba pointed out several years ago there is 'no comprehensive poverty alleviation programmes focusing on the urban poor' (1999:6) in Zimbabwe, a point affirmed by Mpofu (2011b:5). The many radical economic programmes (Mushore 2012) of 'transfer[ring] the country's wealth to the [indigenous] people' (The Chronicle 2014), have suffered from policy inconsistencies worsening urban poverty. ${ }^{6}$ Because of the failed policies independent Zimbabwe remains a land of serious inequality (Mazingi \& Kamidza 2011:359; Chinake 1997:39).

James observes in cities the reign of 'a social order that is crafted to dehumanize and vex the poor and vulnerable while the rich and powerful are rewarded, given preferential treatment and idolized' (2015:58). Zimbabwean scholar Magure (2012:68) corroborates James' analysis by highlighting that Zimbabwean economic life has become riddled with 'a complex network of patrons and clients [that] mediates the allocation of scarce resources'. In this 'neo-patrimonial' process' (Magure 2012:68) the scarce resources, rather than enhancing efficient and effective social

6 The post-independence economic development policies implemented by Robert Mugabe's ZANU-PF party included the 'Growth with Equity' policy of 1981, the Transitional National Development Plan (1982-1985), the First Five-Year National Development Plan (1982-1990), the Second Five Year National Development Plan (19911995), the Economic Structural Adjustment Program (ESAP) from 1991, the Zimbabwe Programme for Economic and Social Transformation (ZIMPREST) launched in April 1998, the Millennium Economic Recovery Programme (MERP) launched in 2001 and National Economic Revival Programme (NERP) of 2003 (Mazingi \& Kamidza 2011:328-342). 
services for the poor, serve public officials' own interests. The poor and the powerless are trampled on. Urban poverty in Zimbabwe thrives on the commoditisation of the poor and economic policies remain based on political patronage. Furthermore, the decline of formal employment has exposed the poor to ruthless capitalistic opportunism that characterise the informal market where prices and quality of commodities are unregulated. The poor have to contend with cheap imports and at times expensive poor quality imports that quickly become unserviceable and have to be replaced.

This section has highlighted the enduring nature of urban poverty in Zimbabwe from the colonial period. The majority of poor urban Africans continue to experience the urban centres as foreign and harsh places. Thus, the urban church is challenged to consider how it can enable poor urbanites to turn urban centres into permanent home, where they can find loved and protected life.

\section{The African Kraal as a metaphor of an empowering urban church}

The African kraal is proposed as a metaphor of a church that can contribute meaningfully towards responding to the problem of economic exclusion of Africans that has exacerbated the context of urban poverty in Zimbabwe.

\subsection{The problematic nature of metaphorical language in theology}

Scripture describes the church in a wide range of metaphors and images to help us understand the nature of the church. The church is depicted in family metaphors like 'bride of Christ' (Eph 5:32), agricultural images like 'an olive tree' (Rom 11:17-24), architectural images like 'a building' (1 Cor 3:9) and images drawn from human anatomy such as 'the body of Christ' (1 Cor 12:12-27). In ecclesiology, according to Dulles (1987:17-18), metaphors illuminate the mystery of the church. Furthermore, metaphors can be useful hermeneutically 'to clarify the significance of concepts within relations' (Louw 2000:46). Grudem affirms that biblical metaphors aid us to 'appreciate more of the richness of privilege that God has given us by incorporating us into church' (1994:859). However, Louw (2000:46) and Grudem (1994:859) show that metaphors can be problematic, complicating and further shrouding the very truth they are employed to shed light on. Therefore, metaphors should be used carefully, not in isolation of other 
metaphors in the Bible. The employment of the African kraal metaphor for the church in this essay is aware of these possible limits and its dangers in distorting the image of a liberating and empowering church.

The metaphor of the African kraal adopted in this essay is derived from indigenous African knowledge and wisdom. Waliggo (1998:111) notes that the doctrine of the church in Africa has been presented in terms that are foreign to most Africans resulting in a weak and poor African church. The African kraal has been chosen because of its potential to promote community building through its integrative elements of communal, spiritual, ethical and economical values. The essay proposes that this communal integrative power can aid the conceptualisation of an urban church that embraces the poor to empower and liberate them in a context of urban poverty.

\subsection{The community building aspects in the African Kraal}

In his essay 'Placing Christianity at the Centre of the Healing and Reawakening of Africa' (2014), Bishop Mvume Dandala of the Methodist Church in South Africa, proposes the metaphor of the African cattle kraal as an image of cajoling the African church into playing a curative role in the increasingly hopeless and broken African continent. The model of the African kraal can be integrated with and enhanced by the view on the 'clan' as is done in Waliggo's The African Clan as Model of African Church (1998), emphasising the significance of fellowship, solidarity and kinship in African life. However, the economic outlook of Waliggo's clan ecclesiology remains at charity level (1998:122), although it does condemn the parasitic tendencies of some family members (1998:124). Tanye (2010) uses the African extended family model to dissuade ethnocentrism among African Christians. However, as will be shown below, the kraal model is preferred because its attitude towards the poor emphasizes empowering them to be responsible and actively contribute in the economic life of the society. ${ }^{7}$

7 A contemporary Ndebele saying condemns those who want to eat and yet lazily sit on their hands. The expression condemns laziness and living off other people. Such sayings are indicators that parasitic attitudes and dependency syndrome are not accepted in African cultures. 
In reference to cattle, kraal is pen or byre, called isibaya in the Nguni languages. Before colonisation, African tribal communities built their homesteads around cattle kraals to protect their livestock from raiding enemies and wild animals (Gaul 1905:121; Walton 1958:133; Nyathi 2001:73). Bishop Thomas Gaul, an early Anglican missionary in colonial Zimbabwe, in his essay 'The Possibilities of an African Kraal' (1905), used African kraal to refer not to the animal pen, but the circular African homesteads. ${ }^{8}$ Gaul (1905:121) however acknowledged that the circular settlements developed from the need to protect the cattle, placing the cattle pens within the settlements. Bishop Dandala (2014) rightly concentrates on the cattle kraal (isibaya) and highlights the economic, social, spiritual and ethical implications that make the cattle kraal central in traditional African existence. Dandala (2014:7) points out:

The kraal is more than a pen of the livestock of a home, for in many African communities the head of a household is buried there.

When a child is born he or she is swathed in a skin of an animal slaughtered in the kraal. When a bride is welcomed in a home she is introduced to this home by planting a spear at the kraal entrance. Family meetings, including extended family meetings are held in or near the kraal. The area in front of a kraal is also recognised as that home's inkundla, a place for gathering. When a son is deviating from the value systems of a home, he is summoned to the kraal to be re-instructed on the right ways to follow. Important rituals of the family are largely performed at the kraal. The seniors of the family preside over these. The wealth of the family, the values of the family and the faith of the family are all held together, with the kraal being the point of convergence.

In this text, Dandala highlights the institutional value of the kraal in both African existence and African worldview. The institution of the kraal employs 'the pivotal concept of inter-connectedness from which life flows, around which it revolves and through which it is held together' (Dandala 2014:6).

8 Bishop Gaul's essay 'The Possibilities of an African Kraal' is more concerned with the African village or homestead and would be more accurate if entitled along the lines of the possibilities of an African village. 
In many southern African tribes, 'the cattle kraal represents the most important ritual space' (Chidester, et. al. 1997:214). ${ }^{9}$ In traditional African life, the kraal denotes the inter-connectedness of existence not as merely abstract concept but by its visible symbols and functions that are instrumental to the existence and flourishing of families and the wider society. The kraal functions economically by being the family's economic storehouse in housing the family's livestock which is a basic source of wealth (Nyathi 2000:46-47; 2001:73) and even as a source of manure for nourishing the farming fields. In other tribes, the grain is stored in underground pits dug in the kraal (Johnson 1993:344; Nyathi 2001:73). As a burial space for the family heads it is the place where the ancestors are appeased and appealed to, making it a place of worship. Marriage rituals are performed in the cattle kraal, while other families bury the umbilical cord of new babies in the kraal, therefore the kraal functions as a temple or shrine by 'symbolis[ing] the meeting point between the visible and invisible worlds' (Nyathi 2005). It has communal and ethical value; in some tribes, the space in front the kraal is a meeting place or the court, the iNkundla (in Nguni languages) or the Lekgotla (in Sotho), for important family issues such as disputes, land, governance and rights of property (Gaul 1905:122; Dandala 2014:7). ${ }^{10}$ The kraal therefore functions as a court (and even a school) for instruction, discipline, justice and reconciliation. Dandala (2014:7) appropriately likens the cattle kraal to the Jewish temple, but a temple located in every home that joins other temples in the community to form the tribal temple that gathers at the chief's place. Therefore, the 'wealth of the family, the values of the family and the faith of the family are all held together, with the kraal being the point of convergence' (Dandala 2014:7). The concept of the African kraal captures the notion of existing together in a mutually beneficial and protective manner.

The institutional framework of the African kraal may be considered within the African communal philosophy of ubuntu (the African view of ideal human behaviour) that emphasises, among other things, hospitability

9 Among the Ndebele people in Zimbabwe, the sacredness of the kraal is further denoted by the setting aside of a black ox as the host of the family ancestors. The designated ox is revered and never used for draught purposes (Nyathi 2000:46).

10 Walton (1958:142) points out: 'The use of the cattle-kraal as a khotla or as a meetingplace for the menfolk was formerly quite general among the Sotho' 
towards the vulnerable as an essential quality of authentic human behaviour (Gathogo 2007:112-123; 2008:44-45; Mateyu 2014:58-92). As expressed in the Nguni proverb umuntu ngumuntu ngabantu, ubuntu emphasises that true humanness is derived from being in community with other human beings and hospitably providing for others, especially the needy and vulnerable members of the society. Among the Ndebele, a hospitable action toward the poor that directly flows from the kraal is a practice called $u k u s i s a$, meaning the temporary assigning of a small herd of cattle to a poor family to raise on behalf of the principal owner. When the cattle are returned to their principal owner, a portion of the increase is permanently allocated to the ownership of the poor family (Nyathi 2000:47). Ukusisa is employed as an act of enabling poor families to establish their own kraal. This must not be seen as feudalism, for although 'in the process the rich became richer, they also empowered others to acquire their own property' (Moyo 1999:53). In traditional African societies the belief in the unity of the cosmos implies that riches ultimately belong to God and the ancestors impose upon the rich the responsibility to share with the poor and to act as insurance against insecurity since the poor could not be refused if they were in need' (Moyo 1999:52). Practices such as these, including communal grannies of the tribal chiefs and kings isiphala senkosi (Machingura 2012:182-183) ensured that there were no street children, vagrants or squatters, and not even geriatric homes in traditional African cultures. Gathogo (2008:40) points out that hospitality, like religion, permeates all the departments of African life. A basic tenet in the African kraal is that all people are 'entitled to basic human rights such as food and accommodation' (Moyo 1999:54). In this sense, the African cattle kraal functions as an institution of building an empowering and liberating community (Moyo 1999:52).

\subsection{The African Kraal as a metaphor of an empowering urban church}

In an urban context where the poor are marginalised, oppressed and exploited, the African kraal can serve as a metaphor of a liberating and empowering urban church by its emphasis on communality that provides a loving home to the poor. The African kraal ultimately symbolises the full extent of home, ikhaya in Ndebele. In rural areas the extended family system provides the poor some form of social security. The urban poor do not often have this support system in times of crisis. Therefore, thinking of the church as an African kraal is imagining the church as a 
hospitable home that protects the marginalised, oppressed and exploited urban poor. Congregational life is extremely essential to African existence because it functions as a support group (Oduyoye 1997:72, 75; Haddad 2001:6). Traditionally, the extended family system forbids letting the poor to perpetually wallow in poverty while the other members were well fed (Moyo 1999:52).

The kraal is a home that empowers spiritually, socially and economically. As an African kraal the urban church must protect the poor by empowering them holistically. Mateyu (2014) emphasises that the church is an ethical community must strive to promote good moral conduct among church members. The church family must liberate the urban poor from impoverishing behaviour and attitudes that hinder them from productively standing on their own. Therefore, the imagery of the kraal challenges the church 'to accept the responsibility for the restoration of the links between faith, wealth creation and responsible living' (Dandala 2014:8). From a kraal perspective, the church is a sacred space for encountering the salvation of the resurrected Christ and also an economic space where God is encountered as the creator, provider and sustainer of life (Gen 1:28-30) and as one who equips and empowers his people to be active economic participants (Gen 2:15). Some respected biblical scholars affirm that addressing poverty is part and parcel of God's mission of saving sinners and being church (Wright 2006:286,288; Longenecker 2010:124,127). Just as in the African kraal there cannot be cohesion and preservation of the community without attending to the needs of the poor, the urban church's worship of the living God who loves life and gives it abundantly (John 10:10; Moltmann 1978:19) must result in a hospitality that affords the urban poor social security.

In the kraal model economic skills and sustainable development should be part and parcel of Christian discipleship. Apostle Paul's statement that 'when we were with you, we gave you this rule: 'The one who will not work, he shall not eat" (2 Thess 3:10) demonstrates that the apostle made economic education a critical component of Christian discipleship. The kraal model challenges the urban church to in-source, rather than out-source, the responsibility of responding to poverty. The church has resources and skills that ought to be harnessed in empowering the urban poor. Some elements of the kraal can be creatively interpreted in the quest for a liberating and 
empowering urban church in Zimbabwe. For example, manure from the cattle - which is essential for nourishing the agricultural fields and the yokes for harnessing the oxen for work - can foster a useful theology of work in a context used to begging and charity. The space outside the kraal that functions in some tribes as a meeting place, inkundla/legotla, depicts the teaching ministry of the church that entails using Scripture teaching, rebuking, correcting and training in righteousness equipping the Christian for good work (2 Tim 3:15) bringing them to holistic maturity.

The church in an urban context of poverty must reinterpret the Eucharist, which is 'the centre of the church unity and reality' (Waliggo 1998:118), not just vertically in relation to God, but also horizontally in relation to the poor and their oppressive socioeconomic and political situation. Offerings and tithes should be reinterpreted as important resources of capital of empowering the poor. Moltmann (1979:21) emphasises that the church is a communal body where there is koinonia (fellowship) and diakonia (service) towards the poor and marginalised people. In the New Testament, fellowship and service underpin the reality of the church as demonstrated by the communal 'one another' passages such as 'be devoted to one another in brotherly love' (Rom 12:10), 'share with God's people who are in need' (Rom 12:13), 'practice hospitality' (Rom 12:13). This means that the church must be a home providing community to the urban poor who find themselves in an environment of deprivation and exclusion and regarded as 'undesirables' (Mpofu 2010) and plunged into 'anonym[ity] and impersonal[ity]...[and] material and psychological deprivation' (Hove, et. al. 2013:14). Oduyoye emphasises that the African church must recognise its role of 'providing an active support base for a people traditionally accustomed to living in caring communities' (1997:72).

The imagery of the church as an African kraal reminds Christians that all their possessions are from God and that the enjoyment thereof must be shared with the poor. Every member is therefore a steward of what ultimately belongs to God (Moyo 1999:52). The Christian community ought to be a community of sharing since it owes its existence to a God who shared his life with humanity in Jesus Christ. It is a community in which all members ought to be keepers of one another. Christians are more than an extended family; they are a universal family of God through Christ (Moyo 1999:57; Tanye 2010). The church is reminded that Jesus Christ to whom it 
submits as Lord (Eph 4:5), is also the Lord of life (John 10:10). Furthermore, in passages such Luke 4:18-19 and Matthew 25:31-46, Jesus has explicitly expressed an option for the poor and powerless which challenges the urban church to be extremely sensitive to the exclusionary tendencies of urban life that often leave the poor vulnerable to all forms of abuses. Reinterpreted in the light of these factors the African kraal can prompt an urban church that creatively engages poverty that surrounds it.

\subsection{The problem of the African Kraal as a metaphor of an urban church}

A serious challenge of the African kraal metaphor lies in its patriarchal nature that leaves women marginalised and oppressed. Haddad has pointed out that a theology of development must recognise 'that unequal power relations exist between men and women' (2001:6). Unequal power relations between men and women significantly contribute to women's loss of property rights and limited access to material wealth leaving them utterly dependent on men for both access and protection of their wealth. Patriarchy creates conditions where men are not accountable to their wives and children in their use of scarce material resources that are critical to family existence. The material welfare of the entire family is often vulnerable to men's poor decisions. This requires that the kraal be de-patriarchalised in order to depict an empowering church.

Furthermore, in the African kraal rights of children are often stifled by projecting them as men's possessions, which encourages exploitation and oppression of girls, such as the marrying away of young girls to older men. This stunts the socioeconomic development of women and further perpetuates women's dependence on men for their socioeconomic wellbeing. Although the Zimbabwe's modern inheritance laws recognise and affirm the equality of the girl-child with the boy-child, socio-cultural norms continue to be underpinned by patriarchal norms that subvert the rights of human equality given to the girl-child by the national constitution. Therefore, when using the African kraal as a metaphor of a liberating and empowering urban church the oppressive patriarchal elements must be replaced with elements that affirm and protect the human dignity of the children, particularly the human dignity of young girls who often find themselves at the lowest end of the social structures. 
In addition, traditional religious beliefs, particularly the idea of limited cosmic good severely restricts the economic viability of the African kraal. As Van Rooy highlights, 'good' refers to the 'vital force, power, prestige, influence, health, good luck' (1999:238). By limited cosmic good is meant the belief that the vital force needed for individuals to attain material prosperity is limited and can run out, and is only available to those with strong magical powers and those well-connected to the super-spiritual powers. This often creates competition instead of co-operation within the community, crippling social cohesion. Furthermore, in Africa the quest for progress and excellence is often stunted by the fear of witchcraft from jealous relatives and neighbours. Fear that evil, envious and jealous neighbours can block one's access to the life-giving cosmic power, prompts life in the African kraal to be characterised by intense religious activity to possess and control the vital sources that enable one to be wealthy and keep others from effectively drawing from it. As a result, rivalry, jealousy, witchcraft and casting spells on others to frustrate their progress, undermine and even undo cohesion and cooperation among community members in the African kraal. Ultimately, more effort is invested in religious efforts that seek to control the cosmic powers than pursuing the physical efforts that bring socioeconomic progress.

The communal nature of the African kraal often translates into a form of communism that breeds dependency instead of interdependence and uniformity and conformity that stifles unprecedented progressive creativity. In some cases, communities overcrowd in unproductive lands unwilling to resettle elsewhere where there is better land because of fear of leaving the graves of their ancestors. However, the understanding of the good life represented by the African kraal can provide an understanding of an empowering communality that can be useful in the development of a theology of poverty eradication in Zimbabwe.

The metaphor of the African kraal can be deemed unfit for an urban context because its rural orientation makes it more suitable in a village setting than in towns and cities. Furthermore, the use of a strongly rural oriented image for an urban problem opens one to the charge of attempting to ruralise urban life in Zimbabwe (Mugumbate, et. al. 2013). Using a rural oriented metaphor to respond to an urban problem further heightens concerns that there is a lack of creative thinking about tackling urban 
poverty (Dhemba 1999:6; Mpofu 2011b:5). Despite its rural orientation, the metaphor of the African kraal is used with reference to the urban church because it represents an empowering and liberating communality that can be translated into an urban situation.

\section{The African Kraal's call to the urban church in Zimbabwe}

What should the church in a context of urban in Zimbabwe do, in the light of the African kraal, in order to respond to poverty meaningfully?

\subsection{A recognition of the dehumanising effects of poverty}

In an urban context where poverty thrives on the foreignization and dehumanisation of the African poor through economic marginalisation and denial of tenure, the metaphor of the African kraal calls for a recognition of the dehumanisation of the poor. The metaphor of the kraal challenges the church to holistically recognise the effects of spiritual sin on humankind and the dehumanising effects of socioeconomic poverty on humanity. Poverty must not be tolerated but must be decisively addressed. Poverty reduces human beings to an extremely dehumanised state of being. Magezi (2007:105) highlights from Hunter that poverty is a 'pain ... a disease ... [that] attacks a person not only materially, but also morally'. Some poor urbanites end up degrading their human dignity by shameful acts such as crime, begging and sleeping in open places. Further drawing from Hunter, Magezi (2007:105) shows that poverty 'eats one's dignity and drives one into despair. Poverty is like living in jail, under bondage, waiting to be free'. The examples of this include many people who end up addicted to drugs and alcohol and many poor women and girl-children who end up forced into commercial sex work where they suffer great abuse and exploitation for basic survival. Zimbabwe continues to witness schoolgoing girls abandoning schooling due to early pregnancy and opting for child marriages in order to survive, further perpetuating the cycle of intergenerational poverty.

South African theologian Dirk Smit underscores that addressing poverty is ethically integral to being the church of Jesus Christ; to fail to see and respond to poverty is tantamount to a lack of ecclesiological integrity. As he aptly expresses it: 
Could it perhaps be that suffering, especially in radical poverty, challenges the Christian church to see in such a fundamental way that the very being of the church is itself at stake? Could it possibly be that, if we fail to see this - to perceive, to accept, and to understand - we fail to remain church? Could it indeed be true that what we do will depend on what we see, what we see will depend on who we are, and what we fail to see will impact on our integrity itself? (Smit 2003:57-58). ${ }^{11}$

The church ceases to be the church of Jesus Christ when it ignores the concrete suffering of the poor and exploited, particularly in view of the dehumanising power of poverty. Smit highlights that the church should not excuse or justify the historical reality of poverty. Drawing from Karl Barth, Smit (2003:58-59) emphasises that the suffering of God's people ultimately violates God's glory because the shame endured by God's supreme creation, humanity, ultimately violates his glory as the supreme creator. Poverty is ultimately God's enemy because it kills and dehumanises what God has so supremely created. Therefore, the church must take seriously all evil forces that cripple people from living authentic human lives by scuttling their breath and harassing them with fear, despair and pain, including poverty (Smit 2003:59).

\subsection{Addressing poverty as an act of self-preservation and self- protection}

A critical factor in the African kraal is the self-preservation and selfprotection of the community by wading off poverty through providing opportunities of empowering the poor for sustainable economic life through practices such as ukusisa. Dandala highlights that when family members deviate from the home's value systems they are 'summoned to the kraal to be re-instructed on the right ways to follow' (2014:7). This is a reciprocal act that preserves and protects the rebellious member and preserves and protects the community by uprooting behaviour that ultimately leads to the disintegration of the society. Lazy people who let their fields lie uncultivated, the irresponsible ones who let their cattle wander into other

11 Smit makes this statement motivated by the call for an ethics-of-seeing from Heinz Eduard Tödt. 
peoples' fields devouring their crops and even those who are intransigent and uncooperative in the community development are summoned to chastisement at the kraal. For those who lack economic means the community consults together seeking solutions to empower them out of poverty. In the kraal, the senior members of the family, the clan or the tribe play a significant role by passing their wisdom to the younger generations. Hence, while guarding against the sacralisation of patriarchy, Dandala (2014:8) summons the church to 'review its ministry structures ensuring that the senior members of family have their authority restored, for them to offer leadership, educate, support and foster accountability'. Without promoting patriarchy, paternalism and social oppression, Dandala affirms the necessity of good authority and leadership in human communities without which there is chaos and no vision. Indeed, the New Testament also affirms the priesthood of all believers while at the same time insisting on good leadership where the older members pass their wisdom to the younger generation (e.g. Acts 6:1-7; 1 Tim 4:7-10). For the church to be a good African kraal, where the poor and powerless are not marginalised and exploited but protected and empowered to be responsible and meaningful socioeconomic players, visionary leadership is non-negotiable.

In many urban African churches, the societies and fellowships that often erupt as support structures in times of emergencies and everyday life demonstrate the need by the poor for churches to function as empowering and liberating communities. While agreeing with Wilson and Ramphele's assessment that churches are better situated to work with poor people than other religious and secular institutions, Haddad finds that churches as institutions are however, generally 'unable to harness for effective social transformation' (2001:12-13). Reasons for this inability include the common tendency of undermining and underutilising the priesthood of all believers through the monopolisation of the ministry of the church by the church hierarchies (Mugambi 1997:11; Ela 2005:23). This means that the church must harness the priesthood of all believers in order to be an effective liberating and empowering community to the urban poor.

\subsection{A gender and child sensitive response to urban poverty}

Women and children bear the brunt of urban poverty. In adopting the African kraal as a model of a liberating and empowering church in a context of urban poverty, the church must be gender and child sensitive. Haddad 
has decried the patriarchal nature of the institutionalised churches that often marginalises women, resulting in women 'devis[ing] their own microdevelopment strategies which harness the resources of both the spiritual and material realms' (Haddad 2001:6). Similarly, Oduyoye (1997:75) found that in the established churches women formed parallel associations and fellowships to promote the cause of women because of marginalisation by the patriarchal church hierarchies. Oduyoye (1997:72) further observed that women exhibited greater loyalty to their associations and fellowships than to the congregation as a whole. This demonstrated that the women derived greater support and fulfilment from 'the support and care provided by the informal Church community more than the ministration provided by the officially appointed ministers and lay leaders of the established structures' (1997:72). This meant that the church had not provided women with the support they needed to overcome their socioeconomic struggles. The urban church is called upon to adopt poverty eradication strategies that are gender and child sensitive.

\subsection{An informed engagement of urban socioeconomic and political reality}

The church, in its search for solutions to urban poverty, should understand this quest as a spiritual activity, but beyond that also a socioeconomic and political activity. Bedford-Strohm suggests that a church's profitable engagement with poverty must exceed the charity model, the advocacy model (fundamentally critical model) and advisory model (political advice model), but must adopt a public theology model that realises the relationship between 'firm moral grounding and economic and political theory' (2008:148). In suggesting the public theology model, Bedford-Strohm is not diminishing the value of the charity, advocacy or the advisory roles. He rather affirms that a meaningful response to poverty must attend to the socioeconomic and political factors. The public theology model functions from the perspective of debating 'the economically most appropriate ways to develop an economy which guarantees a life in dignity for every human being' (Bedford-Strohm 2008:149). This challenges the church's response to be sufficiently informed by the socioeconomic and political dynamics that foster poverty. This means that the urban church must develop a sound public theology that empowers it to understand and engage the unique economic and political matrixes that promote urban poverty. 
However, in Zimbabwe church ministers tend to define the mission of the church very narrowly, and often uncritically resort to divine intervention and avoid critical analyses of the socioeconomic and political factors affecting the country (Chitando \& Manyonganise 2011:101). In other words, church leaders' engagement with issues such as poverty is uninformed by the material dynamics at play. Therefore, in the Zimbabwean context of urban poverty, 'there is [urgent] need to increase the levels of political [and socioeconomic] literacy of many leaders' (Chitando \& Manyonganise 2011:102). The kraal model challenges the dependency syndrome and the secularisation of material possessions amongst churches that cripple an effective Christian engagement with poverty. Urban life is by its nature a survival of the fittest (or as is common in Zimbabwe, also a survival of the politically connected). The urban poor are ravaged daily by the merciless might of the self-aggrandising ruling elites who abuse the poor for their selfish ends. The urban church must develop a critical public theology that enables it to act in urban poverty.

\section{Conclusion}

The church in the urban context of poverty in Zimbabwe can learn from the empowering and liberating nature of the African kraal to structure itself in a manner that enables a meaningful response to urban poverty. As James contends, 'The task of the church is to permeate the urban environment with the Christian joyfulness and hope' (2015:58). In a context where many Africans experience urban centres as inhospitable and hostile foreign places, the church must therefore provide not just a home, but also an empowering and liberating space that enables the African urban poor to respond to their poverty meaningfully. In this, the church is called to remember: 'Where Jesus is, there is life. There is abundant life, vigorous life, loved life and eternal life' (Moltmann 1978:19). To submit to the lordship of Christ the Lord implies for the church in an urban context of poverty to resist unjust suffering, evil and oppressive socioeconomic and political structures that promote premature death and make urban centres into death traps. Following the metaphor of the African kraal, the church can play a meaningful role in a context of urban poverty by recognising the grave effects of poverty on the human dignity of the poor, by providing an empowering home to the excluded and marginalised urban poor, by 
fostering a culture that is gender and child sensitive and by engaging the socioeconomic and political systems that promote urban poverty. This affirms that 'the church is a critical urban asset in perpetuating joyfulness in our cities' (James 2015:59).

\section{Bibliography}

Bedford-Strohm, H 2008. Poverty and Public Theology: Advocacy of the Church in Pluralistic Society. International Journal of Public Theology, 2(2): 144-162.

Chavunduka, GL 1975. Rural and urban life. Zambezia, 4(II): 69-78.

Chidester, D, Kwenda, C, Petty, R, Tobler, J \& Wratten, D 1997. African traditional religion in South Africa: an annotated bibliography. Westport: Greenwood.

Chinake, H 1997. Strategies for Poverty Alleviation in Zimbabwe. Journal of Sustainable Development in Africa, 12(1): 39-51.

Chitando, E \& Manyonganise, M 2011. Voices from faith-based communities. In Zimbabwe in transition: a view from within, edited by T Murithi \& A Mawadza. Pretoria: The Institute of Justice and Reconciliation: 77-111.

Chung, F 2006. Re-living the Second Chimurenga: memories from the liberation struggle in Zimbabwe. Uppsala: Nordic African Institute.

Cubitt, VS 1979. The urban poverty datum line in Rhodesia: a study of the minimum consumption needs of families (1974). Salisbury: University of Rhodesia. [Online] Available: http://opendocs.ids.ac.uk/opendocs/bitstream/ handle/123456789/9992/Cubbit\%2cV.S.\%201979\%20supplement\%20to\%20the\%20 urban\%20porverty\%20datum\%20line\%20\%20\%28faculty\%20of\%20social\%20 studies\%29.pdf?sequence=1\&isAllowed=y [Accessed: 2016, July 27].

Cubitt, V.S. \& Riddell, R.S. 1974. The urban poverty datum in Rhodesia: a study of the minimum consumption needs of families. Salisbury: University of Rhodesia. [Online] Available: http://opendocs.ids.ac.uk/ opendocs/bitstream/handle/123456789/7557/Cubitt,\%20VS\%20\%26\%20Riddell,\%20 RC\%20\%20The\%20Urban\%20PDL\%20In\%20Rhodesia\%20(Book\%20Chapter). pdf?sequence $=1$ [Accessed: 2016, July 27]. 
DailyNews Live. 2015. Celebrating sending graduates to streets. DailyNews Live. [Online] Available: http://www.dailynews.co.zw/ articles/2015/10/14/celebrating-sending-graduates-to-streets [Accessed: 2015, November 20].

Dandala, HM 2014. Placing Christianity at the centre of the healing and re-awakening of Africa. Unpublished paper. Stellenbosch: Stellenbosch University.

Dhemba, J 1999. Informal Sector Development: A Strategy for Alleviating Urban Poverty in Zimbabwe. Journal of Social Development in Africa, 14(2): 5-19.

Dulles, A 1987. Models of the Church. $2^{\text {nd }}$ Ed. Dublin: Gill \& Macmillan.

Gathogo, JM 2007. Revisiting African hospitality in post-colonial Africa. Missionalia 35:2 (August 2007), 108-130.

Gathogo, JM 2008. African philosophy as expressed in the concepts of hospitality and ubuntu. Journal of Theology for Southern Africa 130, $39-53$.

Gaul, C 1905. The possibilities of an African kraal. The East and the West: a quarterly review of the study of missions 3, 121-129.

Grudem, WA 1994. Systematic theology: an introduction to biblical doctrine. Leicester: IVP.

Haddad, B 2001. Theologising development: a gendered analysis of poverty, survival and faith. Journal of Theology for Southern Africa 10, 5-19.

Hove, M, Ngwerume, ET \& Muchemwa, C 2013. The urban crisis in Sub-Saharan Africa: A threat to human security and sustainable development. Stability: International Journal of Security and Development, 2(1):1-14. [Online]: Available: http://www.stabilityjournal.org/ articles/10.5334/sta.ap/ [2016, September 16]

James, G 2015. Urban theology endeavours and a theological vision of hope and justice for post-apartheid South African cities. Stellenbosch Theological Journal, 1(2): 43-68. 
Johnson, MP 1993. African healers: Called to be Isangoma or prophet. In The transcendent function: individual and collective aspects, edited by M. Matton. Einsiedeln: Daiman Verlag, 343-352.

Longenecker, BW 2010. Remember the poor: Paul, poverty and the GrecoRoman world. Grand Rapids: W.B. Eerdmans.

Machingura, F 2012. The Messianic Feeding of the Masses: An Analysis of John 6 in the Context of Messianic Leadership in Post-colonial Zimbabwe. Bamberg: University of Bamberg.

Magezi, V 2007. HIV/AIDS, Poverty and pastoral care and counselling. Stellenbosch: African Sun Media.

Magure, B 2012. Foreign investment, black economic empowerment and militarised patronage politics in Zimbabwe. Journal of Contemporary African Studies, 30(1): 67-82.

Mateyu, SF 2014. The church as an ethical community: a paradigm for Christian ethics in an African context. An Unpublished MA thesis. Potchefstroom: North West University.

Mazingi, L \& Kamidza, R 2011. Inequality in Zimbabwe. In Tearing us Apart: Inequalities in Southern Africa, edited by $\mathrm{H}$ Jauch \& D Muchena, Open Society Initiative for Southern Africa: 322-382. [Online] Available: http://www.osisa.org/sites/default/files/sup_files/ chapter_5_-_zimbabwe.pdf [Accessed: 2016, April 13].

Moltmann, J 1978. The open church: invitation to a messianic lifestyle. MD Meeks (ed.). London: SCM.

Moltmann, J 1979. The diaconal church in the context of the kingdom of God. In Hope for the church: Moltmann in dialogue with practical theology, edited by T Runyon. Nashville: Abingdon: 21-36.

Moyo, A 1999. Material things in African society: implication for Christian ethics. In Moral and ethical issues in African Christianity: a challenge for African Christianity, edited by JNK Mugambi \& A Nasimiyu-Wasike. Nairobi: Acton: 49-57. 
Mpofu, B 2010. No place for 'undesirables': the urban poor's struggle for survival in Bulawayo, Zimbabwe, 1960-2005. Unpublished PhD Thesis. Edinburgh: University of Edinburgh.

Mpofu, B 2011a. Operation 'Live Well' or 'Cry Well'? An Analysis of the 'Rebuilding' Programme in Bulawayo, Zimbabwe. Journal of Southern African Studies, 37(1): 177-192.

Mpofu, B. 2011b. Some Perceptions on the Poverty Question in Zimbabwe. Solidarity Peace Trust. [Online] Available: http://www. solidaritypeacetrust.org/download/essays/The\%20Poverty\%20Question\%20in\%20 Zimbabwe.pdf [Accessed: 2014, August 27].

Mugumbate, J, Maushe, F \& Nyoni, C 2013. Ruralisation of urban areas: reversing development in Zimbabwe. International Journal of Advanced Research in Management and Social Sciences, 2(7): 13-30.

Mushore, W 2012. Media construction of reality: a critical analysis of the reportage of land reform in Shona and English Zimbabwean newspapers: the case of Kwayedza, The Herald, The Daily News and The Daily Mirror, 2000-2008. Unpublished DPhil et Litt Thesis. Pretoria: University of South Africa.

Mutasa, B 2015. UN unemployment statistics misleading. [Online] Southern Eye. Available: http://www.southerneye.co.zw/2015/01/26/ununemployment-statistics-misleading/ [Accessed: 2016, April 26].

Mateyu, SF 2014. The church as an ethical community: a paradigm for Christian ethics in African context. Unpublished MA thesis. Potchefstroom: North West University.

NewsDay Zimbabwe. 2015. Graduating to become a vendor, taxi pirate. [Online] Available: https://www.newsday.co.zw/2015/10/13/graduating-tobecome-a-vendor-taxi-pirate/ [Accessed: 2015, November 20].

Nyathi, P 2000. Alvord Mabena: the man and his roots: a biography. Harare: Priority Projects.

Nyathi, P 2001. Traditional ceremonies of Amandebele. Gweru: Mambo. Nyathi, P 2005. Zimbabwe's cultural heritage. Bulawayo: amaBooks. 
Oduyoye, MA 1997. The future of the church in Africa: its mission and theology. In. The church and reconstruction of Africa: theological considerations, edited by J. N. Mugambi. Nairobi: AACC: 66-83.

Smit, DJ 2003. On learning to see? A reformed perspective on the church and the poor. In Poverty, suffering and HIV-AIDS: international practical theological perspectives, edited by P. D. Couture \& B. J. Miller-McLemore. Cardiff: Cardiff Academie: 55-70.

Southern Eye. 2015. ILO Zim's jobless rate illusionary. Southern Eye. [Online] Available: http://www.southerneye.co.zw/2015/01/23/ilo-zims-joblessrate-illusionary/ [Accessed: 2016, April 26].

Tanye, GK 2010. The Church-as-family and ethnocentrism in sub-Saharan Africa. Berlin: LIT.

The Chronicle. 2014. Zim marks unique day. [Online] Available: http://www. chronicle.co.zw/zim-marks-unique-day/ [Accessed: 2016, April 26].

The Herald. 2015. 'Zim's unemployment level up 11,3\%' [Online] Available: http://www.herald.co.zw/zims-unemployment-level-up-113-pc/ [Accessed: 2016, April 27].

Van Rooy, JA 1999. The Christian gospel as a basis for escape from poverty in Africa. In In die Skriflig/In Luce Verbi, 33(2): 235-254.

Waliggo, JM 1998. The African clan as the true model of the African church. In JN Mugambi \& L Magesa, The church in African Christianity: innovative essays in ecclesiology. Nairobi: Acton, 111-127.

Walton, J 1958. Sotho cattle-kraals. The South African Archaeological Bulletin 13/52, 133-143.

Wright, CJH 2006. The mission of God: unlocking the Bible's grand narrative. Nottingham: IVP.

ZimStat, 2014. Zimbabwe National Statistics. [Online] Available: http:// www.zimstat.co.zw/welcome-to-zimstat?qt-statistics_at_a_glance=4\#qt-statistics_ at_a_glance [Accessed: 2016, April 27] 